\title{
Scorpions from the rainforest canopy of Laos, with the description of a new species of Lychas C.L. Koch, 1845 (Scorpiones: Buthidae)
}

\section{Скорпионы из крон деревьев дождевого леса Ааоса с описанием нового вида рода Lychas C.L. Koch, 1845 (Scorpiones: Buthidae)}

\author{
Wilson R. Lourenço \\ Вимьсон Р. Аоуренсо
}

Muséum national d'Histoire naturelle, Département Systématique et Evolution, UMR7205, CP 053, 57 rue Cuvier, 75005 Paris, France. E-mail: arachne@mnhn.fr

Национальный музей естественной истории, Париж, Франция.

KEY WORDS: scorpion, Buthidae, Lychas, new species, Laos, rainforest, canopy.

КЛЮЧЕВЫЕ СЛОВА: скорпион, Buthidae, Lychas, новый вид, Лаос, дождевой лес, кроны деревьев.

ABSTRACT. A new species, Lychas aberlenci sp.n., is described from the rainforest canopy of Khammouane Province in Laos. The new species is characterized by a moderate size as compared to the congeners, the total length of the male measuring $49.8 \mathrm{~mm}$. The coloration is pale yellowish to reddish-yellow with a conspicuous, inverted triangular, blackish spot at the anterior margin of the carapace. The pectines are with 29-30 teeth in the male, the highest number so far observed in a Lychas species; fulcra are present, being conspicuous. With the description of $L$. aberlenci sp.n., the number of known Lychas species in Laos is increased to three.

РЕЗЮМЕ. ОПисан новый вид, Lychas aberlenci sp.n., из крон деревьев дождевого тропического леса в провинции Хаммуан в Лаосе. Новый вид характеризуется умеренными размерами по сравнению с другими видами рода, у самцов достигая общей длины в 49,8 мм. Окраска бледно желтоватая до красновато-желтой с явственным черноватым пятном в форме обращенного вершиной вниз треугольника у переднего края карапакса. Пектины у самца с 29-30 зубами, и это самое высокое их число среди видов Lychas; фулькры имеются, явственные. С описанием L. aberlenci sp.n. число видов Lychas, известных из Лаоса, выросло до трех.

\section{Introduction}

As discussed in previous publications [Lourenço \& Qi, 2007], scorpions from tropical rainforest canopies are little-known, with only very few examples documented yet. Lourenço [1997] provided a checklist of such examples, mainly relating to species of the genus Tityus C.L. Koch, 1836 (Buthidae) from the tropical rainforest of South America. Subsequently, other species of Tityus have also been reported from the canopy of the Amazon forest [Lourenço \& Pézier, 2002] and a new species, Tityus canopensis Lourenço et Pézier, 2002, living exclusively in the canopy has been described.

A few years ago, a survey effectuated in New Guinea included a collection of several scorpion specimens taken from canopy by means of fogging. A study of these scorpions revealed a single species belonging to the genus Lychas C.L. Koch, 1845 [Lourenço \& Qi, 2007]. The only Lychas reported to that date from New Guinea had been Lychas variatus papuanus (Thorell, 1888) [see also Fet \& Lowe, 2000]. After examining the type material of this latter subspecies the canopy population was identified as a different subspecies, Lychas variatus canopensis Lourenço et Qi, 2007, distinct both in its considerably smaller size and its peculiar habitat from L. variatus papuanus, a soildwelling taxon.

A recent inventory was carried out on rainforest canopy fauna in the Khammouane Province in Laos during the IBCFL, Canopy Operation ('Radeau des Cimes'), which took place during the North Asian spring of 2012. This Canopy Operation led to the collection of a few scorpions, all belonging to the genus Lychas C.L. Koch, 1845, family Buthidae C.L. Koch, 1837. All of the specimens but one proved to represent $L$. mucronatus (Fabricius, 1798), a species common in Asia and Southeast Asia. The sole exception, an adult male, was confirmed to belong to a new species, being described here.

\section{The genus Lychas in Laos and Vietnam}

The genus Lychas comprises a complex group of species of buthid scorpions. These show a variety of grades of evolutionary development [Lourenço, 2011]. 


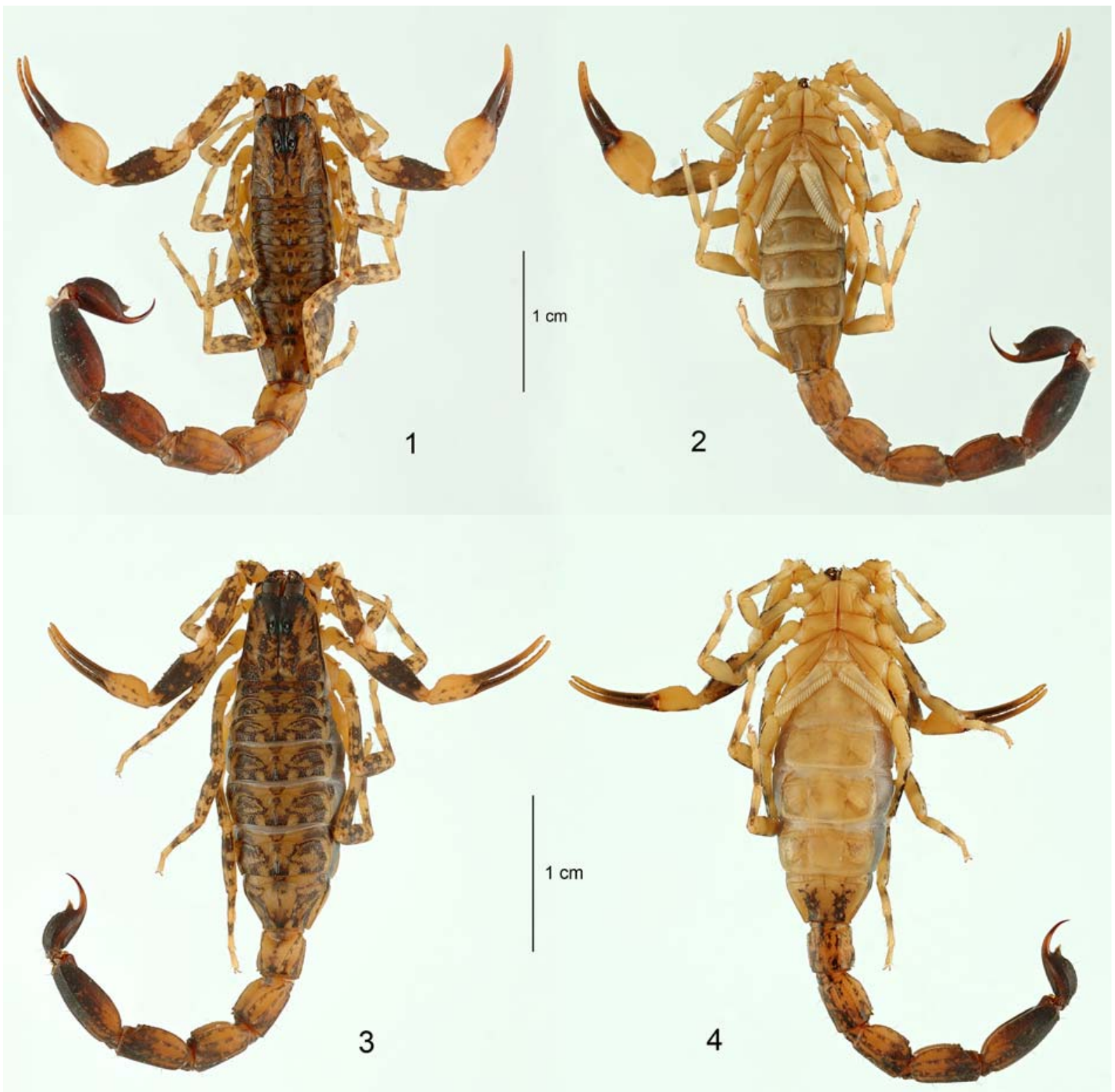

Figs 1-4. Lychas mucronatus (Fabricius, 1798) from the canopy in Laos rainforest: $1-2-$ male; $3-4-$ female, dorsal and ventral aspects of habitus, respectively.

Pис. 1-4. Lychas mucronatus (Fabricius, 1798) из крон деревьев дождевого леса в Лаосе: 1-2 - самец; 3-4 - самка, габитус соответственно сверху и снизу.

The range of geographical distribution of the genus is very large, with different species in Africa, Asia, Australia and some Pacific islands [Fet \& Lowe, 2000]. An even greater range of palaeodistribution of Lychas or its proto-elements is also suggested by fossil amber evidence from the Baltic region [Lourenço \& Weitschat, 1996; Lourenço, 2012].

The different grades of evolutionary development presented by the species of Lychas were originally outlined by Vachon [1986] in his precise diagnosis of the genus. For instance, some characters such as fulcra in the pectines can be either present or absent, depending on species. Variation in the number of pectinal teeth is also unusually important for diagnostic purposes among the species of the genus.

A number of species have been described and/or reported from Asia. This number is, however, much more limited when it concerns Laos and Vietnam, the countries in which the rainforests of Khammouane Province are distributed. In the 'Catalog of the Scorpions of the World', only Lychas mucronatus has been reported from there [Fet \& Lowe, 2000]. Very recently, a second species, Lychas inexpectatus Lourenço, 2011, was described from northern Laos [Lourenço, 2011]. The evolutionary grade of development shown by $L$. inexpectatus appears to be basal, whereas the features 


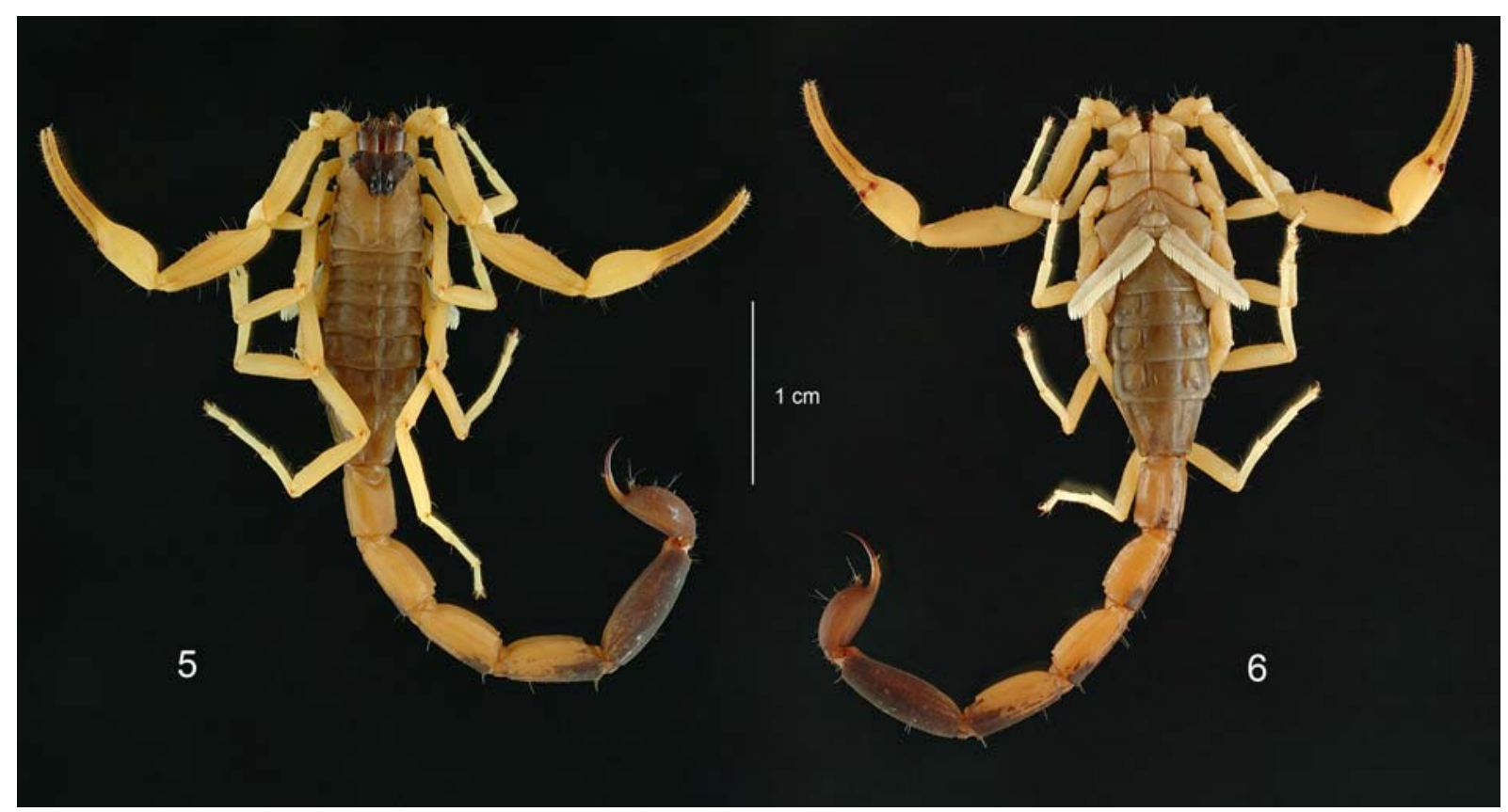

Figs 5-6. Lychas aberlenci sp.n., holotype, dorsal and ventral aspects of habitus, respectively.

Рис. 5-6. Lychas aberlenci sp.n., голотип, габитус соответственно сверху и снизу.

of Lychas mucronatus and the new species described here can be placed at a much higher evolutionary level.

\section{Material and methods}

The holotype is temporarily housed in the collections of the Muséum national d'Histoire naturelle, Paris. It will be subsequently deposited in the collections of the 'future' Natural History Museum of Laos. The studied material of Lychas mucronatus is partly deposited in the Muséum national d'Histoire naturelle, Paris; some specimens are in the collections of the CIRAD, UMR CBGP (INRA/IRD/Cirad/Montpellier SupAgro), while some others in the collections of the 'future' Natural History Museum of Laos. Soil material from the same region is deposited in the Zoological Museum, State University of Moscow, Russia. Illustrations and measurements were produced using a Wild M5 stereo-microscope with a drawing tube and an ocular micrometer. Measurements follow Stahnke [1970] and are given in $\mathrm{mm}$. Line drawings and photographs are not executed to scale. Trichobothrial notations follow Vachon [1974], while morphological terminology mostly follows Vachon [1952] and Hjelle [1990].

\section{Taxonomic part}

Buthidae C.L. Koch, 1837

Lychas C.L. Koch, 1845

Lychas mucronatus (Fabricius, 1798)

Figs 1-4.
MATERIAL COLLECTED IN THE RAINFOREST CANOPY OF LAOS: Laos, Khammouane Province, Hin Boun Ban Nathan River, 'Camp de $1^{\prime}$ Igame', $17^{\circ} 59.645^{\prime}$ N, $14^{\circ} 49.352^{\prime}$ E, 6.V.2012, IBCFL, 'Opération Canopée', leg. H.-P. Aberlenc \& S. Collard, $1 \mathrm{O}^{7}$; Idem, 13.V.2012, $1 \mathrm{O}^{7}$; Idem, 14.V.2012, 1 ㅇ; Idem, 8.V.2012, $1 \mathrm{O}^{7}, 1$ \% ; Idem, 8.V.2012, $1 \mathrm{O}^{2}$ (together with the holotype of Lychas aberlenci sp.n.), all leg. H.-P. Aberlenc; Idem, 18.V.2012, Ikos 'forêt de pente Karstique, leg. J.-Y. Serein, 10 '.

SOIL MATERIAL: Laos, Khammouane Province, $\mathrm{N}$ of Boualapha, X.1978, leg. B. Dejenbol, $3 \bigcirc^{7} \sigma^{7}, 9$ 우.

\section{Lychas aberlenci sp.n.}

Figs 5-14.

MATERIAL. HOLOTYPE O'. Laos, Khammouane Province, Hin Boun River, Ban Nathan Village, 'Camp de l'Agame', $17^{\circ} 59.645^{\prime} \mathrm{N}, 104^{\circ} 49.352^{\prime} \mathrm{E}, 8 . \mathrm{V} .2012$, IBCFL, 'Opération Canopée', leg. H.-P. Aberlenc.

NAME. Honours Henri-Pierre Aberlenc, CIRAD, Montpellier, who collected the new species with the help of Jean-Yves Serein and Noui Baiben.

DIAGNOSIS. A scorpion of moderate size as compared to the other congeners, $\sigma^{7}$ measuring $49.6 \mathrm{~mm}$ in total length. The general coloration is yellowish to reddish-yellow with a conspicuous, inverted triangular, blackish spot at the anterior margin of the carapace, extending from lateral to median eyes. Carinae and granulations are moderately to weakly marked. The carapace is moderately emarginated. The median ocular tubercle is located anterior to the centre of the carapace; the median eyes are moderate and globular. The pectines are large; pectinal teeth count 29-30 for the male holotype, the highest number so far observed for a Lychas species; fulcra are present, being conspicuous. Dentate margins of the fixed and movable fingers of the pedipalp chela are with 6 or 7 almost linear rows 

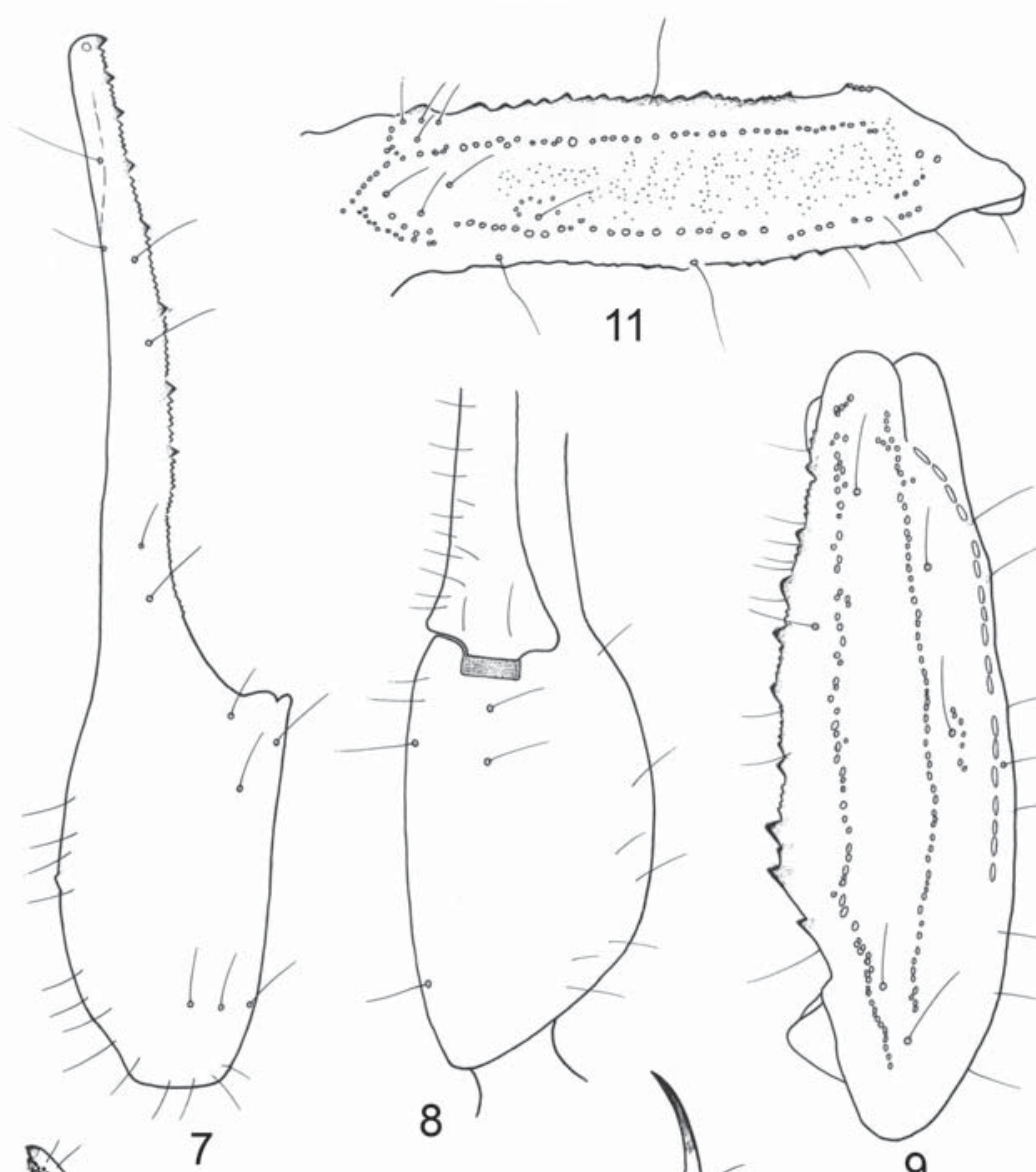

11

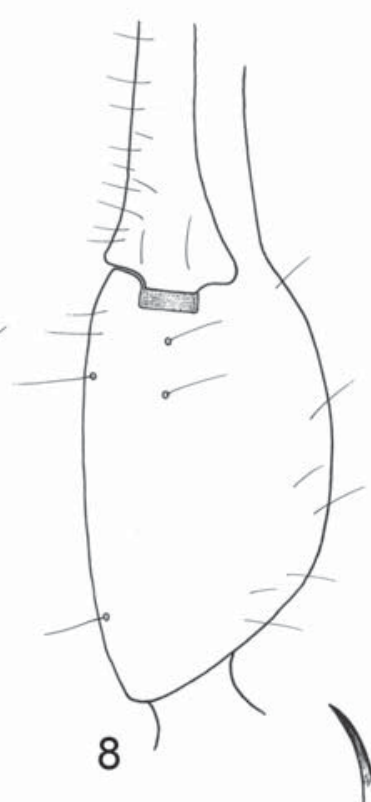

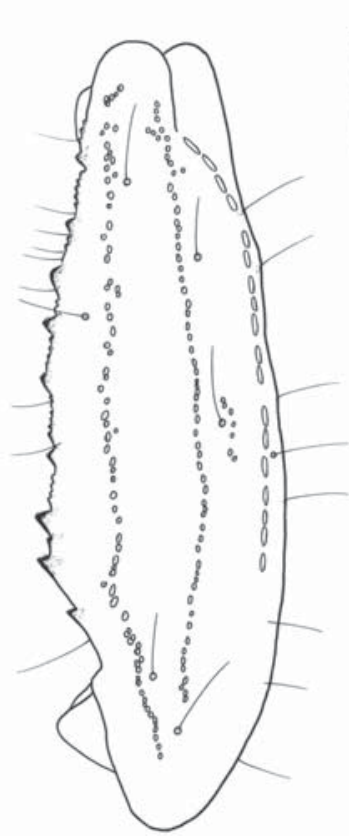

9

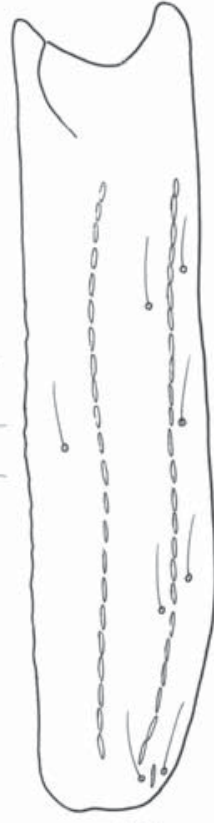

10

12
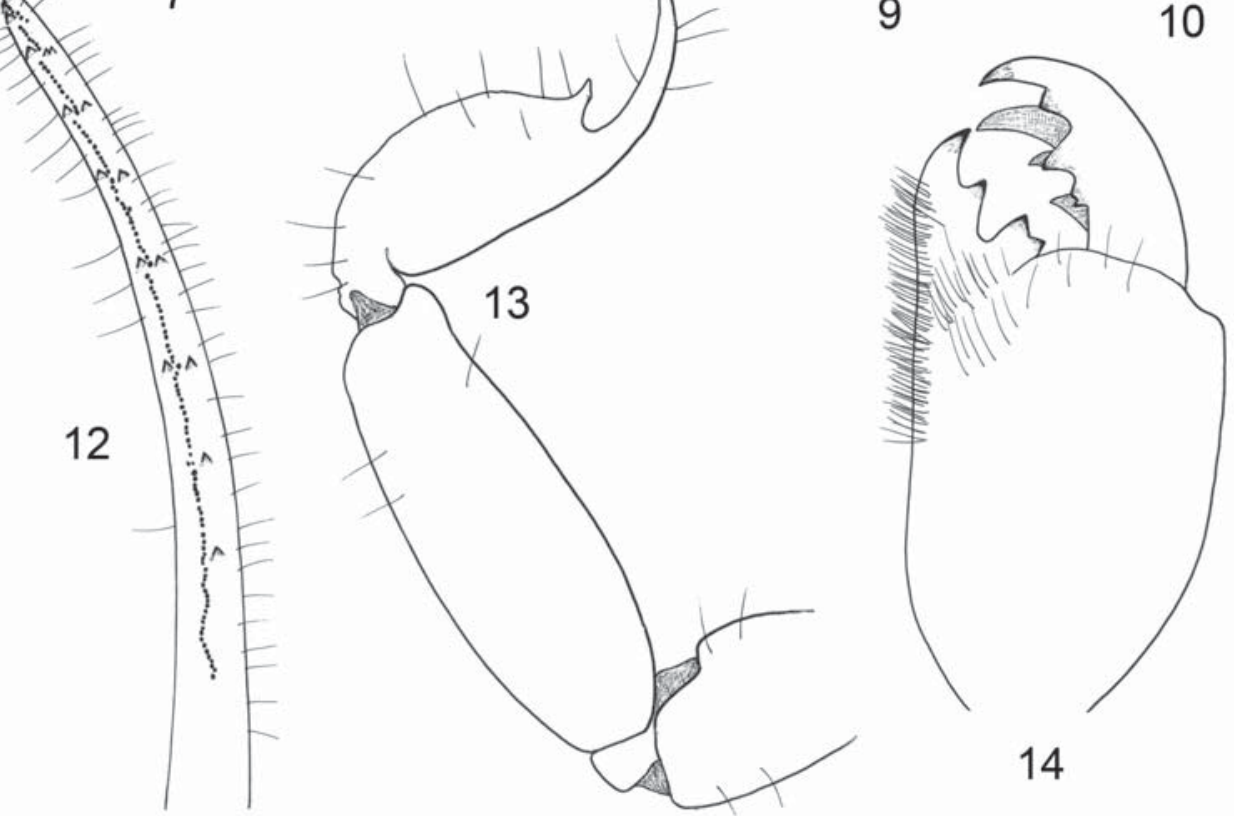

14

Figs 7-14 Lychas aberlenci sp.n., holotype: 7-11 - trichobothrial pattern; 7-8 - chela, dorso-external and ventral aspects, respectively; 9-10 - patella, dorsal and external aspects, respectively; 11 - femur, dorsal aspect; 12 - dentate margin of movable finger, showing rows of granules; 13 - metasomal segment $\mathrm{V}$ and telson, lateral aspect; 14 - chelicera, dorsal aspect.

Рис. 7-14. Lychas aberlenci sp.n., голотип: 7-11 - характер трихоботриотаксии; 7-8 - хела, соответственно одновременно сверху и снаружи, а также снизу; 9-10 - пателла, соответственно сверху и снаружи; 11 - фемур, сверху; 12 - зубчатый край подвижного пальца с рядами гранул; 13 - сегмент 5 метасомы и тельсон, сбоку; 14 - хелицера, сверху. 


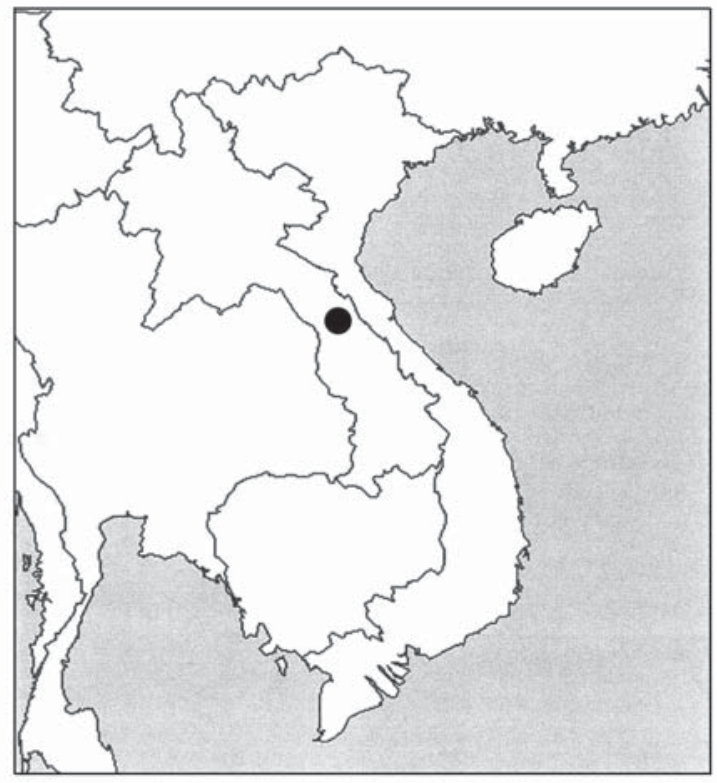

Fig. 15. Map of Southeast Asia, showing the type locality of Lychas aberlenci sp.n. in the Khammouane Province, Laos.

Рис. 15. Карта Юго-Восточной Азии с указанием типового локалитета Lychas aberlenci sp.n. в провинции Хаммуан (Лаос).

of granules (see taxonomic remarks); one or two conspicuous external accessory granules are located next to the basalmost row of granules. The chela has an inconspicuous scalloping of the proximal dentate margin of the fixed finger in the male. The subaculear tubercle is strong and spinoid in shape; ventral granules conspicuous.

RELATIONSHIPS. Based on its general appearance, $L$. aberlenci sp.n. is markedly different from all of the other congeners, in particular from L. mucronatus, a species also distributed in Laos and Vietnam. It can, however, be characterized by a number of features: (i) an overall yellow to reddish-yellow coloration with a conspicuous, inverted triangular, blackish spot at the anterior margin of the carapace; (ii) a size similar to that of L. mucronatus, but with markedly distinct morphometric values (see Table); (iii) very large pectines with 29-30 teeth, the highest number observed so far for a Lychas species; fulcra are present, being conspicuous.

DESCRIPTION. Coloration. Generally yellowish to reddish-yellow with some dark spots on metasoma. Prosoma: carapace reddish-yellow with a conspicuous, inverted triangular, blackish spot at anterior margin, extending from lateral to median eyes; some blackish spots also at lateral edges. Mesosoma: tergites reddishyellow to slightly brownish. Venter, coxapophysis, sternum and genital operculum yellow; pectines pale yellow; sternites pale brown. Metasomal segments IIV reddish-yellow, marked with dark spots ventrally; segments IV and V more intensely marked; V reddishbrown. Vesicle reddish-brown; aculeus yellow at base and dark reddish at its extremity. Chelicerae brownish, intensely marked with dark variegated spots which cover its entire surface; fingers and teeth reddish-brown. Pedipalps yellow, without spots; chela yellow, with rows of reddish granules at dentate margins of fingers. Legs pale yellow.

Prosoma: anterior margin of carapace moderately emarginate. Carapace carinae weak; anterior median and posterior median carinae weak; other carinae obsolete. Intercarinal spaces weakly granular. Median ocular tubercle anterior to the centre of carapace; median eyes of moderate size and globular, separated by 1.5 ocular diameters. Three pairs of lateral eyes. Mesosoma: tergites I-VI with a median carina; weak to obsolete on I, moderate on II-VI. Tergite VII pentacarinate, with lateral pairs of carinae moderate; median carinae present in proximal half, moderately developed. Intercarinal spaces with weakly to moderately marked granulations, slightly stronger than that of carapace. Sternites without granulations, smooth with a moderate setation; spiracles long; sternite VII with four carinae. Pectines very long; pectinal teeth count 29-30; fulcra present and conspicuous. Metasomal segments I and II with 10 carinae, weakly crenulate; III and IV with 8 carinae, weakly crenulate. Segment V with five vestigial carinae, rounded; intermediate carinae on segment II represented by a few granules; any marked posterior spinoid granules on dorsal carinae of segments I-IV absent. Dorsal furrows of all segments very weakly developed, without granulations; intercarinal spaces weakly granular. Telson elongated and non-granular, smooth; aculeus strongly curved and only slightly shorter than vesicle; subaculear tubercle strong and spinoid in shape; ventral granules conspicuous. Chelicerae with dentition characteristic of the buthids [Vachon, 1963]; two small, but well distinct basal teeth on movable finger. Pedipalps: femur pentacarinate; all carinae moderately crenulate. Patella with seven carinae, moderately crenulate; dorso-internal carinae with 7 or 8 slightly spinoid granules. Chela without carinae, smooth. Intercarinal spaces almost smooth on femur and patella. Dentate margins on movable and fixed fingers composed of 6 or 7 linear rows of granules; 1 or 2 conspicuous external accessory granules next to basalmost row of granules. Chela with an inconspicuous scalloping of proximal dentate margin of fixed finger in $\sigma^{7}$. Trichobothrial pattern type A, orthobothriotaxic [Vachon, 1974]; dorsal trichobothria of femur in $\beta$ configuration [Vachon, 1975]. Legs: ventral aspect of tarsi with a brush-like group of setae. Tibial spurs present on legs III and IV, weakly to moderately developed; pedal spurs present on all legs; reduced on legs I and II.

\section{Ecology of the area}

The rainforests in which the new species was collected (Figs 15-17) are situated in an area where the Central Indochina Limestone meets the Annamite Chain. As a result, this area has prominent limestone escarp- 

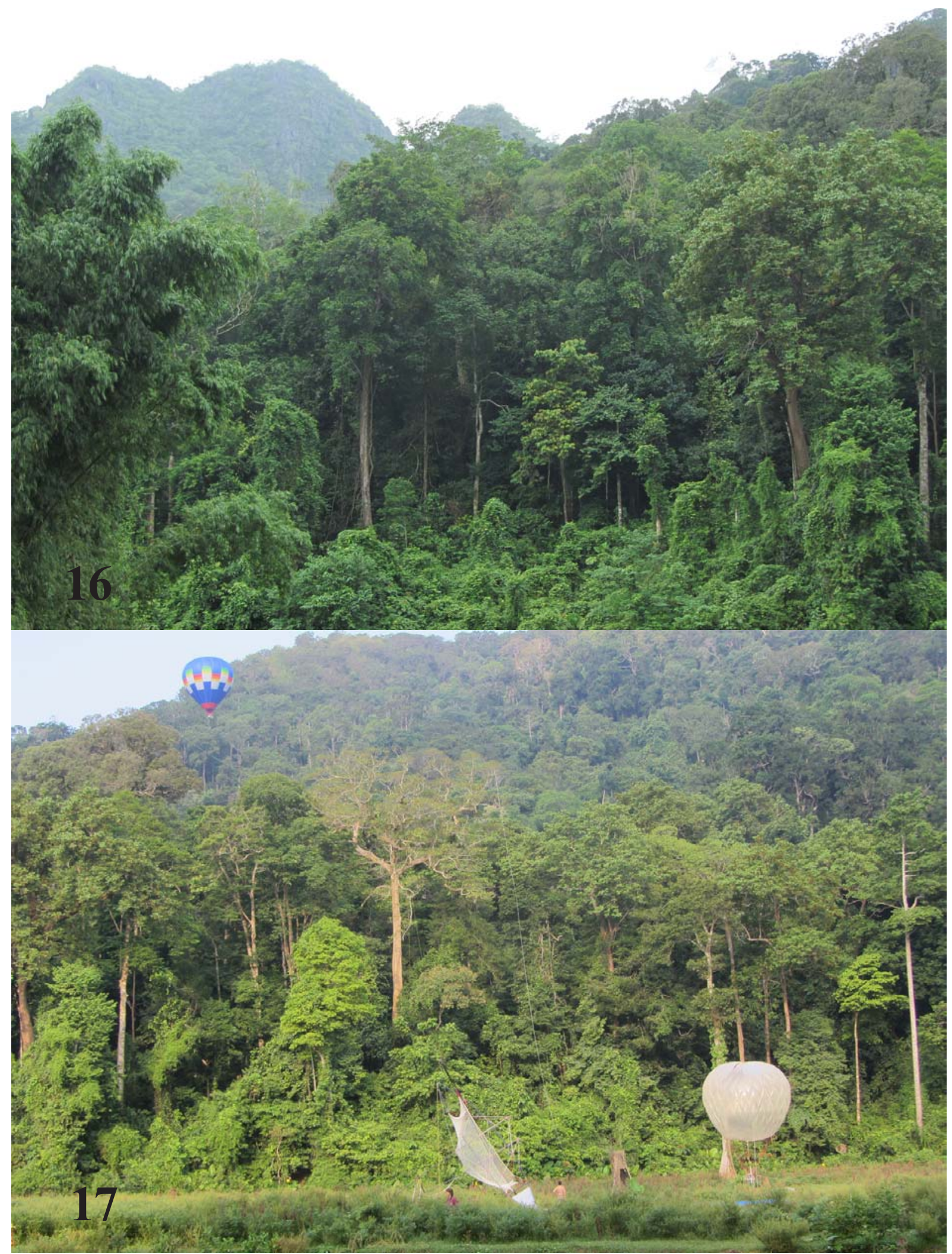

Figs 16-17. The rainforest in the Khammouane Province in Laos. In Figure 17, one can observe a field action during the IBCFL, Canopy Operation.

Рис. 16-17. Дождевой лес в провинции Хаммуан (Лаос). На рис. 17 можно увидеть полевые работы во время Операции Кроны Деревьев проекта IBCFL. 
Table. Morphometric values (in $\mathrm{mm}$ ) of the $\odot^{\top}$ holotype of Lychas aberlenci sp.n. and of the $\odot^{7}$ and $\bigcirc$ of Lychas mucronatus from Laos, also collected in the canopy.

Таблица. Морфометрические данные (в мм) по О голотипу Lychas aberlenci sp.n., а также по О и и 9 Lychas mucronatus из Лаоса, тоже собранных в кронах деревьев.

\begin{tabular}{|c|c|c|c|}
\hline & Lychas aberlenci & \multicolumn{2}{|c|}{ Lychas mucronatus } \\
\hline & holotype & male & female \\
\hline Total length & $43.3\left(49.8^{*}\right)$ & $43.8\left(49.6^{*}\right)$ & $41.9\left(47.1^{*}\right)$ \\
\hline $\begin{array}{l}\text { Carapace: } \\
\text { - length } \\
\text { - anterior width } \\
\text { - posterior width }\end{array}$ & $\begin{array}{l}5.3 \\
3.6 \\
5.3\end{array}$ & $\begin{array}{l}6.0 \\
3.9 \\
5.6\end{array}$ & $\begin{array}{l}5.5 \\
3.6 \\
5.7\end{array}$ \\
\hline Mesosoma length & 11.6 & 13.4 & 15.2 \\
\hline $\begin{array}{l}\text { Metasomal segment I: } \\
\text { - length } \\
\text { - width }\end{array}$ & $\begin{array}{l}3.9 \\
2.8\end{array}$ & $\begin{array}{l}3.4 \\
3.6\end{array}$ & $\begin{array}{l}3.1 \\
3.2\end{array}$ \\
\hline $\begin{array}{l}\text { Metasomal segment V: } \\
\text { - length } \\
\text { - width } \\
\text { - depth }\end{array}$ & $\begin{array}{l}7.5 \\
2.5 \\
2.5\end{array}$ & $\begin{array}{l}7.1 \\
3.4 \\
2.8 \\
\end{array}$ & $\begin{array}{l}6.2 \\
2.7 \\
2.5\end{array}$ \\
\hline Telson length & 6.5 & 5.8 & 5.2 \\
\hline $\begin{array}{l}\text { Vesicle: } \\
\text { - width } \\
\text { - depth } \\
\end{array}$ & $\begin{array}{l}2.0 \\
2.1\end{array}$ & $\begin{array}{l}2.4 \\
2.3\end{array}$ & $\begin{array}{l}1.9 \\
1.8 \\
\end{array}$ \\
\hline $\begin{array}{l}\text { Pedipalp } \\
\text { - Femur length } \\
\text { - Femur width } \\
\text { - Patella length } \\
\text { - Patella width } \\
\text { - Chela length } \\
\text { - Chela width } \\
\text { - Chela depth }\end{array}$ & $\begin{array}{c}6.1 \\
1.7 \\
6.8 \\
2.0 \\
10.3 \\
2.1 \\
2.0 \\
\end{array}$ & $\begin{array}{c}5.7 \\
1.9 \\
6.2 \\
2.3 \\
10.5 \\
3.3 \\
2.8 \\
\end{array}$ & $\begin{array}{l}4.9 \\
1.5 \\
5.5 \\
2.0 \\
8.6 \\
1.7 \\
1.6\end{array}$ \\
\hline $\begin{array}{l}\text { Movable finger: } \\
\text { - length }\end{array}$ & 6.9 & 6.3 & 5.9 \\
\hline
\end{tabular}

* Including telson length

ments and many caves [Mouret, 2001]. The specific zone where the forests are located is placed in the Northern Annamite ecoregion [Mouret, 2001]. The area shows a mosaic of semi-evergreen and mixed deciduous forests, whilst pockets of closed canopy evergreen forest are found within the karstic zones. Further, there are areas of secondary forest, shifting cultivation and bamboo forest. Due to difficult access, much of the forest in the region is free from extensive exploitation, with the exception of areas near roads and villages.

Lychas mucronatus found in the canopy is also common at the ground level, being a typical epigean species. The new species, however, might prove to be a canopy-dweller. Only further collections in the rainforests of the Khammouane Province may reveal if L. aberlenci sp.n. is also present in the soil.

ACKNOWLEDGEMENTS. I am grateful to H.-P. Aberlenc, CIRAD, Montpellier for arranging the facilities for my study of the new material, to Jean-Yves Serein and Noui Baiben who collected arthropods in the canopy, to the the National Council of Sciences of Laos, to Jean-François Reumaux of Animo, to the MAVA Foundation, to the Canopy Operation team (Prof. Francis Hallé, Françoise Cleyet-Marrel, Dany Cleyet-Marrel, Gilles Ebersolt, Laurent Pyot and Philippe Gaboriaud), to Jean-Louis Couderc and his wife Vinh. Special thanks are due to Prof. John L. CloudsleyThompson, London for reviewing the manuscript and to 
Elise-Anne Leguin, MNHN, Paris for her help with the photos and plates.

\section{References}

Fet V., Lowe, G. 2000. Family Buthidae C. L. Koch, 1837 // Fet V., Sissom W.D., Lowe G. \& Braunwalder M.E. (eds.). Catalog of the scorpions of the world (1758-1998) // The New York Entomological Society, New York. P.54-286.

Hjelle J.T. 1990. Anatomy and morphology // Polis G.A. (ed.). The Biology of Scorpions // Stanford University Press, Stanford. P.9-63.

Lourenço W.R. 1997. Additions à la faune de scorpions néotropicaux (Arachnida) // Revue suisse de Zoologie. T.104. Fasc.XXX. P.587-604.

Lourenço W.R. 2011. The "Ananteris group" (Scorpiones: Buthidae); suggested composition and possible links with other buthids // Boletin de la Sociedad Entomológica Aragonesa. T.48. P.105-113.

Lourenco W.R. 2012. Further considerations on the scorpions found in Baltic amber and description of a new species (Scorpiones, Buthidae) // Euscorpius. No.146. P.1-7.

Lourenço W.R., Pézier A. 2002. Addition to the scorpion fauna of the Manaus region (Brazil), with a description of two new species of Tityus from the canopy // Amazoniana. Bd.17. P.177186.

Lourenço W.R., Qi J.-X. 2007. Scorpions from the rainforest canopy of New Guinea and description of a new subspecies of Lychas C.L. Koch, 1845 (Scorpiones: Buthidae) // Bulletin de l'Institut Royal des Sciences naturelles de Belgique. T.77. P.157-161.
Lourenço W.R., Weitschat W. 1996. More than 120 years after its description the enigmatic status of the genus of the Baltic amber scorpion 'Tityus eogenus' Menge, 1869 can finally be clarified // Mitteilungen aus dem Geologisch-Paläontologischen Institut der Universität Hamburg. Bd.79. P.183-193.

Mouret C. 2001. Le karst du Kammouane au Laos central. Dix ans de recherches spéléologiques // Spelunca. T.84. P.7-32.

Stahnke H.L. 1970. Scorpion nomenclature and mensuration // Entomological News. Vol.81. P.297-316.

Vachon M. 1952. Etudes sur les scorpions. Alger: Publications de l'Institut Pasteur d'Algérie. 482 p.

Vachon M. 1963. De l'utilité, en systématique, d'une nomenclature des dents des chélicères chez les Scorpions // Bulletin du Muséum national d'Histoire naturelle, Paris. 2ème sér. T.35. P.161-166.

Vachon M. 1974. Etude des caractères utilisés pour classer les familles et les genres de Scorpions (Arachnides). 1. La trichobothriotaxie en arachnologie. Sigles trichobothriaux et types de trichobothriotaxie chez les Scorpions // Bulletin du Muséum national d'Histoire naturelle, Paris. 3ème sér. T.140. P.857958.

Vachon M. 1975. Sur l'utilisation de la trichobothriotaxie du bras des pédipalpes des Scorpions (Arachnides) dans le classement des genres de la famille des Buthidae Simon // Comptes Rendus de l'Académie des Sciences, Paris. Sér.D. T.281. P.15971599.

Vachon M. 1986. Etude de la denture des doigts des pédipalpes chez les Scorpions du genre Lychas C.L. Koch, 1845 (Arachnida, Scorpiones, Buthidae) // Bulletin du Muséum national d'Histoire naturelle, Paris. T.8. P.835-850.

Responsible editor S.I. Golovatch 